\title{
Condensation of alkylazulenes with thiophene-2-carboxaldehyde and the corresponding azomethines
}

\author{
Alexandru C. Razus, Liviu Birzan, Victorita Tecuceanu, Mihaela Cristea, \\ and Cristian Enache \\ Institute of Organic Chemistry “C. D. Nenitzescu” of Romanian Academy, Spl. Independentei 202 B, \\ 060023-Bucharest 35, P.O. Box 108, Romania \\ E-mail:1birzan@cco.ro
}

\begin{abstract}
The reactivity of 4-, 8- and/or 6-azulene methyl groups in condensation with thiophene-2carboxaldehyde or the corresponding azomethines in basic media was studied. The compounds obtained and the yields depend on the starting materials as well as on the base used. Besides mono- and di(2-(thien-2-yl)vinyl)azulenes, many carbonyl derivatives and other more complicated compounds were obtained and characterized. Amounts of oligomers and polymers are also formed, with unassigned structures. Starting from di- or trimethyl-substituted azulenes, more that one methyl group can be involved in the condensation.
\end{abstract}

Keywords: Alkylazulene, thiophene-2-carboxaldehyde, condensation

\section{Introduction}

Recently, we reported the synthesis of 1-(2-(thien-2-yl)vinyl)azulenes ${ }^{1}$ which were electrochemically polymerized with the formation of good conducting films due to special headto-tail polymerization (C3 of azulene with $\mathrm{C} 5$ of thiophene). ${ }^{2}$ It was of interest to find if the isomers with a 2-(thien-2-yl)vinyl group linked to the seven-membered azulene ring would have ineresting electrochemical properties or if they could be used as materials with nonlinear optical properties. We therefore report now an investigation of the pathways for the synthesis of such substituted azulenes and also the structure assignment of the products obtained. Despite the existence of other protocols for the generation of azulenic compounds that are substituted with 2arylvinyl groups ${ }^{3}$ which occur with higher stereoselectivity as compared to the condensation of alkylazulenes with carbonyl derivatives, we have preferred the latter procedure because it uses commercially available starting materials.

It is well known that, due to the hyperconjugation of alkyl at the 4-, 6- or 8-positions of an azulene, the $\mathrm{C}_{\alpha}$ protons of the alkyl groups can be removed using a strong base. The resulting 
carbanion will react with aldehydes or imines, with the generation of alkenes. A careful study on the "anil synthesis"4 of styrylazulenes was already published by Briquet and Hansen." They condensed guaiazulene and 4,6,8-trimethylazulene, with several 4-substituted "benzanils", in the presence of $\mathrm{KOH}$ in dimethylformamide solution. As expected, the condensation of guaiazulene took place at the 4-methyl, the most acidic alkyl group, whereas the methyl at the 6-position was the first to be attacked when 4,6,8-trimethylazulene was used. The resulting products and the yields obtained depended on the $\mathrm{X}$-substituent in $4-\mathrm{XC}_{6} \mathrm{H}_{4}-\mathrm{CH}=\mathrm{N}-\mathrm{Ph}$. Thus, starting from guaiazulene, if the 4 position was substituted with dimethylamino the yield of styrylazulene was higher than $80 \%$ however, it was only $30 \%$ for $4-\mathrm{H}, 4-\mathrm{Cl}$ or $4-\mathrm{OCH}_{3}$ substituted anils. Moreover, several compounds, resulting from a subsequent condensation or dimerization, were found in low amounts in the reaction mixture. It is interesting to note that for $\mathrm{X}=\mathrm{NO}_{2}$ the reaction with guaiazulene generated 1,2-bis(guaiazulenyl)ethene. Starting from 4,6,8-trimethylazulene only products of addition to the azomethinic double bond are obtained. We set out to establish the regioselectivity of the reaction of thiophene-2-carboxaldehyde or the corresponding azomethines with alkylated azulenes and to isolate and characterize the possible subsequent reaction products.

\section{Results and Discussion}

\section{Condensation of alkylazulenes with thiophene-2-carboxaldehyde and corresponding azomethines}

All the studied condensations of alkylazulenes with thiophene-anils occurred in DMF solution, in the presence of potassium hydroxide as condensing agent. ${ }^{4,5}$ To avoid the Cannizzaro reaction when an aromatic aldehyde was used as starting reagent, $\mathrm{KOH}$ was replaced by sodium N-methylanilide.

\subsection{Condensation of guaiazulene}

1.1.1. Condensation with 2 -thiophene-anils, $2 R$ (Scheme 1). The thiopheneanils were obtained from thiophene-2-carboxaldehyde and anilines with different substituents at the 4-position namely, nitro, methoxy and dimethylamino. From the condensation with guaiazulene, besides the expected alkene 4, the compound 5, containing two guaiazulen-1-yl and one thien-2yl moieties, was isolated. As shown in Table 1, starting from $2 \mathrm{NO}_{2}$ or $2 \mathrm{OCH}_{3}$ the same overall yield in products was obtained. However, the ratio $4: 5$ was inverted. While a great amount of alkene 4 was obtained from $2 \mathrm{NO}_{2}$ the compound $\mathbf{5}$ is the main product starting from $\mathbf{2} \mathrm{OCH}_{3}$. The azomethine $2 \mathrm{~N}\left(\mathrm{CH}_{3}\right)_{2}$ reacted in lower yield but the same ratio $4: 5$ was observed as in the case of $2 \mathrm{OCH}_{3}$. 
Table 1. Condensation of thiopheneanils or thiophene-2-carboxaldehyde with guaiazulene

\begin{tabular}{lcccc}
\hline \multicolumn{1}{c}{$\begin{array}{c}\text { Carbonyl } \\
\text { derivative }\end{array}$} & \multicolumn{5}{c}{ Products $^{\mathrm{a}}$} & $(\%)^{\mathrm{b}}$ & $\mathbf{8}$ & $\mathbf{9}$ \\
\hline $\mathbf{2} \mathrm{NO}_{2}$ & 61 & $\mathbf{5}$ & - & - \\
$\mathbf{2} \mathrm{OCH}_{3}$ & 24 & 54 & - & - \\
$\mathbf{2} \mathrm{N}_{3}\left(\mathrm{CH}_{3}\right)_{2}$ & 6 & 18 & - & - \\
$\mathbf{6}$ & 19 & 0 & 28 & 26 \\
\hline
\end{tabular}

${ }^{\mathrm{a}}$ Variable amounts of tar was obtained in all studied condensation. ${ }^{\mathrm{b}}$ The yields are calculated taking into account the amount of reacted azulene.

The foregoing results are consistent with the proposed reaction pathway described in Scheme 1. We assume that the anion (3R) is obtained in a reversible nucleophilic addition of anion $\mathbf{1}^{-}$to azomethine 2R (step a). The stability of the intermediate decreases with increases in the electron releasing capacity of the substituent $\mathrm{R}$. Therefore, the equilibrium is displaced towards the left for $\mathrm{R}=\mathrm{N}\left(\mathrm{CH}_{3}\right)_{2}$ and to the right for $\mathrm{R}=\mathrm{NO}_{2}$. We believe that the persistence in the strong alkaline medium of unreacted azomethine $2 \mathrm{~N}\left(\mathrm{CH}_{3}\right)_{2}$ results in its hydrolysis followed by a Cannizzaro reaction. This is the explanation for the low yields obtained starting from $2 \mathrm{~N}\left(\mathrm{CH}_{3}\right)_{2}$. It is possible that the formation of the double bond (step b) may take place through a four-centre transition step in which the protonation of the intermediate $(3 R)^{-}$is not necessary. This protonation, however, generates the intermediate $3 \mathrm{R}$ (step c) that cannot be identified in the reaction mixture. ${ }^{7}$ The nucleophilic substitution of the "anil" group in intermediate $3 \mathrm{R}$ with the anion $\mathbf{1}^{-}$(step d) gives bis(azulenyl) derivative 5. Therefore, the reaction route $(a+b)$ to yield the alkene 4 was adopted mainly by azomethine $2 \mathrm{NO}_{2}$ whereas the starting compounds $2 \mathrm{OCH}_{3}$ and $2 \mathrm{~N}\left(\mathrm{CH}_{3}\right)_{2}$ followed the reaction sequence $(\mathrm{a}+\mathrm{c}+\mathrm{d})$ that leads to the substituted propane $\mathbf{5}$. The dependence of yield and product ratio on the starting azomethine, as shown in Table 1, is in accordance with the proposed mechanism. 


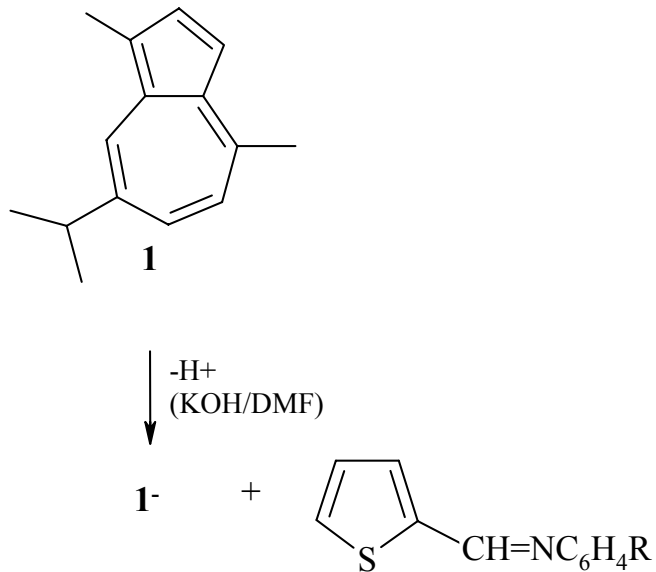

$2 \mathrm{R}$ (a)

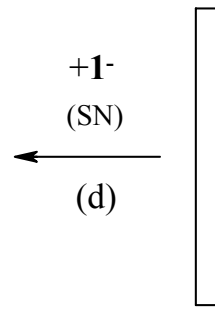

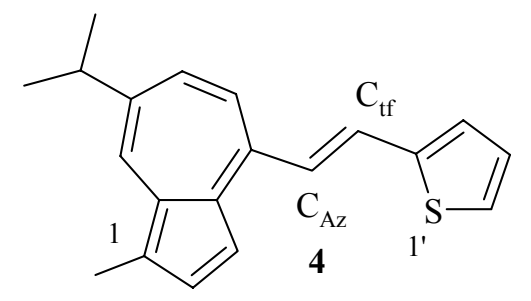

(b)

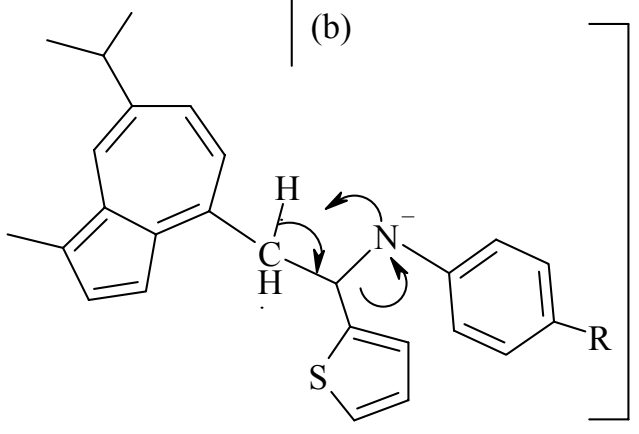

(3 R)

(c) $\mid \begin{aligned} & +\mathrm{H}_{2} \mathrm{O} \\ & -\mathrm{HO}^{-}\end{aligned}$<smiles>[R]c1ccc(NC(Cc2ccc(C(C)C)cc2-c2ccccc2)c2cccs2)cc1</smiles>

$3 \mathrm{R}$

5

\section{Scheme 1}

1.1.2. Condensation with thiophene-2-carboxaldehyde, 6 (Scheme 2). Due to our interest in the synthesis of (2-(thien-2-yl)vinyl)-azulenes, which are substituted at the seven-membered ring, we attempted to avoid the nucleophilic substitution, which decreased the alkene yield. In this aim, we started from thiophene-2-carboxaldehyde, 6, instead of its azomethines. Starting from the aldehyde, the alcoholate anion, 7, generated as intermediate, cannot be involved in a nucleophilic substitution.

Even under the milder conditions produced by the use of sodium $N$-methylanilide as condensation agent, the yield in alkene was reduced due to other side reactions. Because an excess of aldehyde was necessary, the ketone $\mathbf{8}$ was formed from the alcoholate 7 in an Oppenauer oxidation (Table 1). Subsequently, by the reaction of ketone $\mathbf{8}$ with aldehyde $\mathbf{6}$, the unsaturated ketone 9 was obtained. This condensation was promoted by the high reactivity of methylene group in ketone $\mathbf{8}$. 

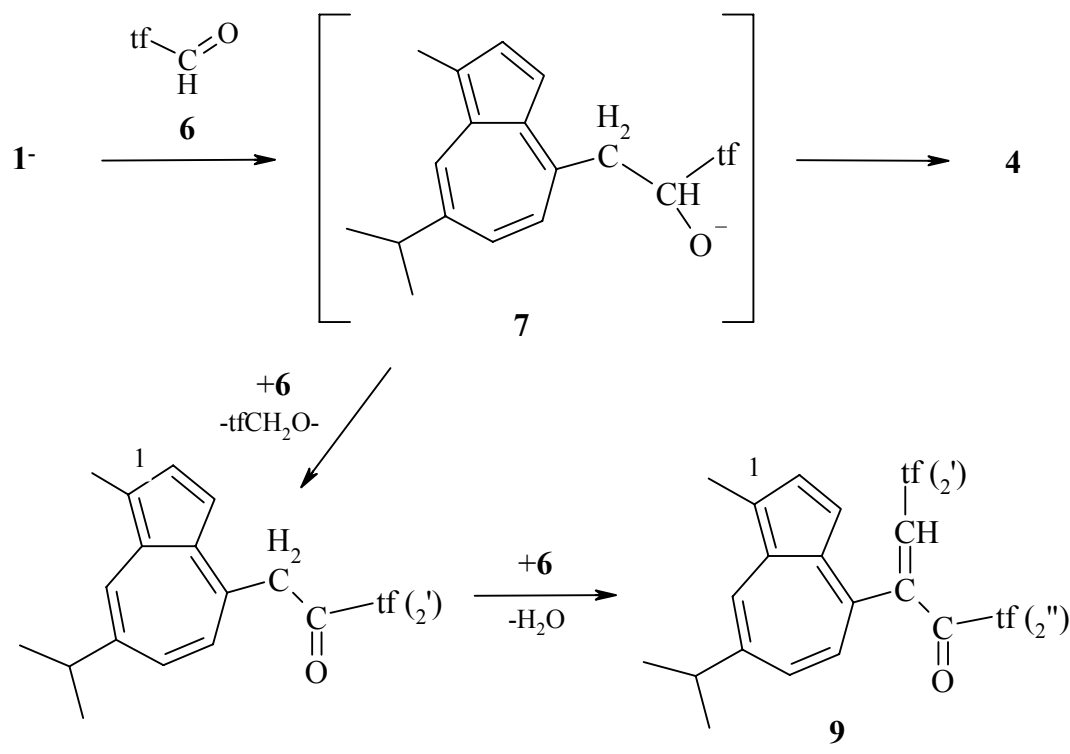

8

$\operatorname{tf}\left({ }_{n}\right)=\prod_{S}$

$(\mathrm{n})=$ the atom numbering in NMR spectra

\section{Scheme 2}

\subsection{Condensation of 6-tert-butyl-4,8-dimethylazulene}

While guaiazulene possesses only one acidic methyl, two such groups could be involved in condensation of 6-t-butyl-4,8-dimethylazulene, 10. Hansen, ${ }^{8}$ who has studied the condensation of compound 10 with benzaldehyde in the presence of $t$-BuOK in tetrahydrofuran at room temperature, reported the formation of a mixture of mono- and bis(styryl) derivatives. Therefore, we were interested to establish the regioselectivity of the condensation of azulene $\mathbf{1 0}$ with thiophene-2-carboxaldehyde $\mathbf{6}$ or corresponding azomethines $\mathbf{2}$.

1.2.1. Condensation with 2-thiopheneanils, 2 (Scheme 3). The reaction of 2-OCH $\mathrm{H}_{3}$ or $2-\mathrm{NO}_{2}$ with azulene 10 to give $\mathbf{1 1}$ occurred in disappointing yields. "Biazulenyl" $\mathbf{1 2}$ and "triazulenyl" 13 were also isolated from the large amount of the tar formed (in the reaction mixture several other "oligomers" were signaled by LC-MS analysis). In this condensation there were no significant differences in the efficiency whichever azomethine was used. Because of the lower reactivity of the azulene $\mathbf{1 0}$ as compared with $\mathbf{1}$, hydrolysis of used azomethines occurred to a greater extent before the reaction with the azulene could take place. The aldehyde formed was consumed in secondary reactions. An amount of tar was also obtained due to the two reactive positions in the used azulene $\mathbf{1 0}$ which allowed the polycondensation. 


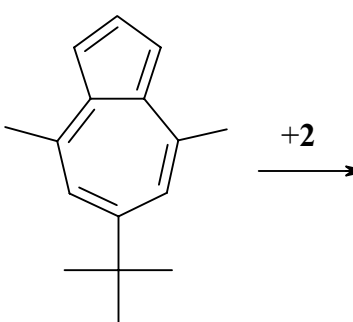

10

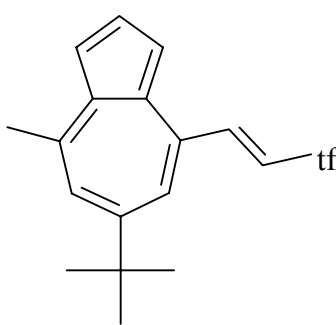

11

$4 \%$ starting form $2 \mathrm{OCH}_{3}$ or $2 \mathrm{NO}_{2}$

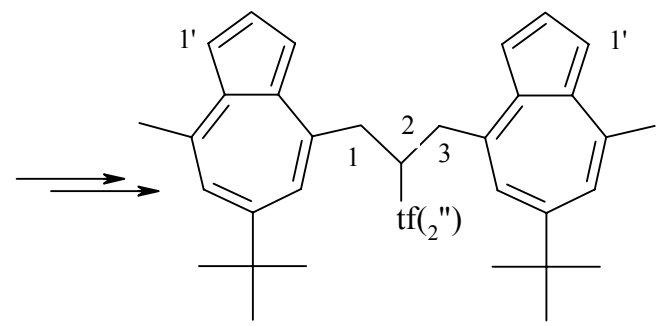

12

$6 \%$ starting from $2 \mathrm{OCH}_{3}$ $\sim 3 \%$ starting from $2 \mathrm{NO}_{2}$

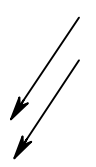

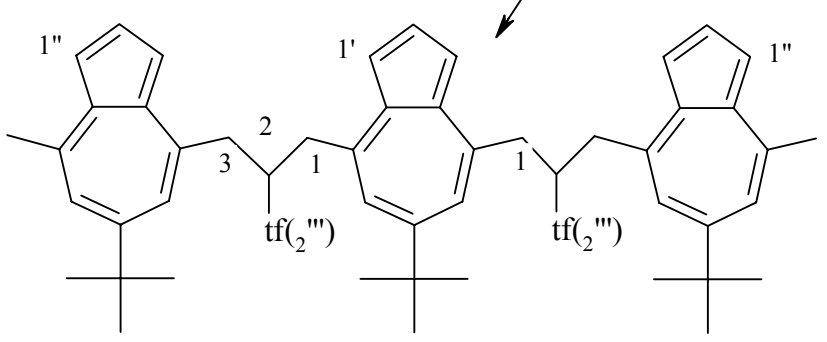

13

$(>2 \%)$

\section{Scheme 3}

1.2.2. Condensation with thiophene-2-carboxaldehyde, 6 (Scheme 4). The higher stability of thiophene-2-carboxaldehyde in the presence of sodium $N$-methylanilide ensured the presence of this compound in the reaction medium for long enough for condensation with azulene. As in the reaction of guaiazulene, the condensation products were mainly ketones, namely, 15 and 16, but diketone 17 was also detected by LC-MS analysis. From the reaction mixture the divinyl compound 14 was isolated and characterized. 


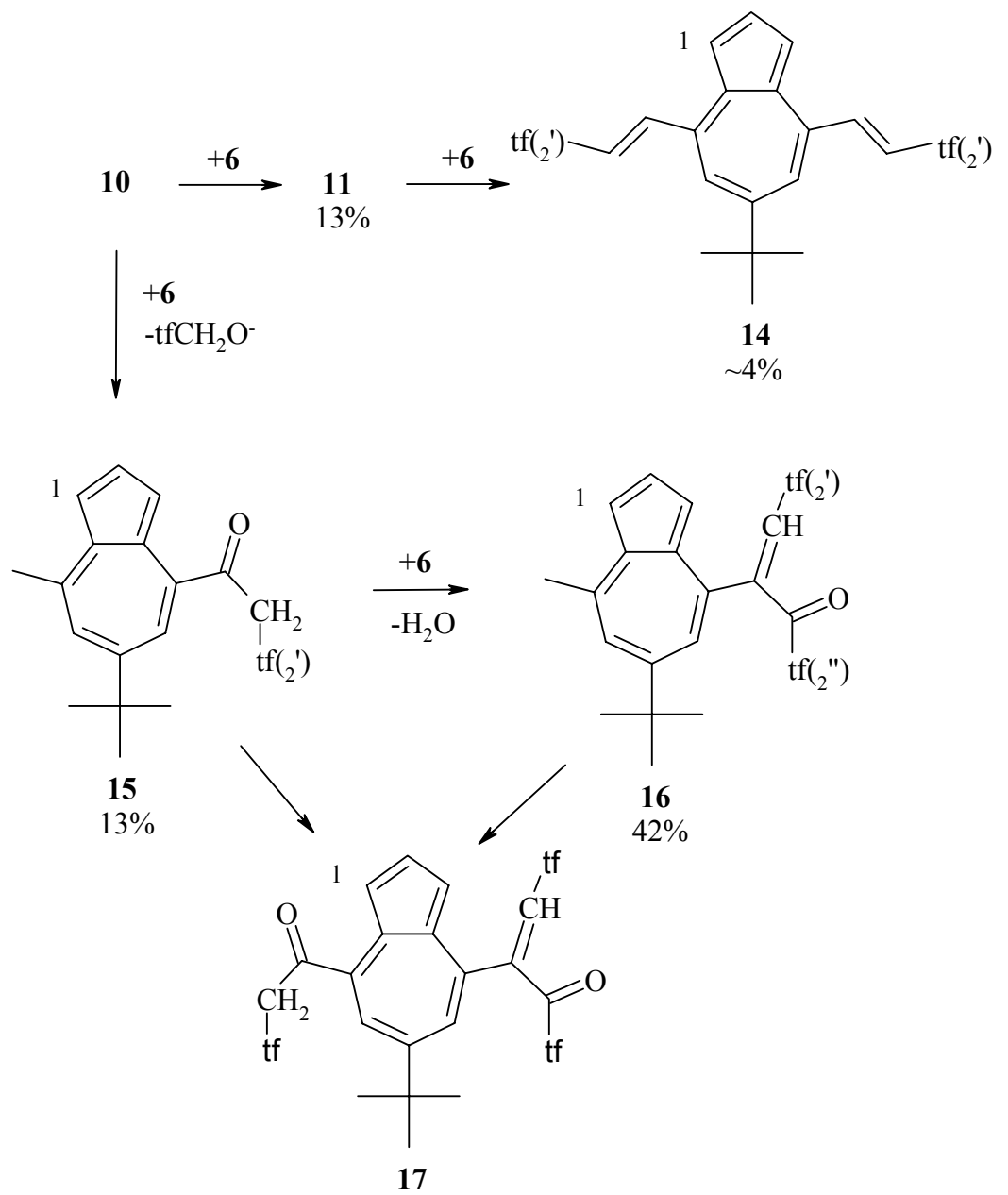

\section{Scheme 4}

\subsection{Condensation of 4,6,8-trimethylazulene}

If the methyl groups in azulene $\mathbf{1 0}$ posses the same reactivity, the methyls in 4 and 8 position of 4,6,8-trimethylazulene, 18, have the tendency to generate kinetic controlled products of condensation whereas the methyl in 6 position gives thermodynamic ones.

As is shown in Scheme 5, the reaction with azomethine occurred at the methyl at C6 and generated in small amounts the compounds $\mathbf{1 9}$ and $\mathbf{2 0}$ together with the compound $\mathbf{2 1}$ in which, besides the 6 position, the 4 position was also involved.

The condensation of $\mathbf{1 0}$ with thiophene-2-carboxaldehyde showed the presence of a higher amount of compounds substituted at C6, 19 and 24, as compared with the compounds substituted at $\mathrm{C} 4,22$ and $\mathbf{2 5}$. Therefore, we assume that the last reaction is possibly thermodynamically controlled. 


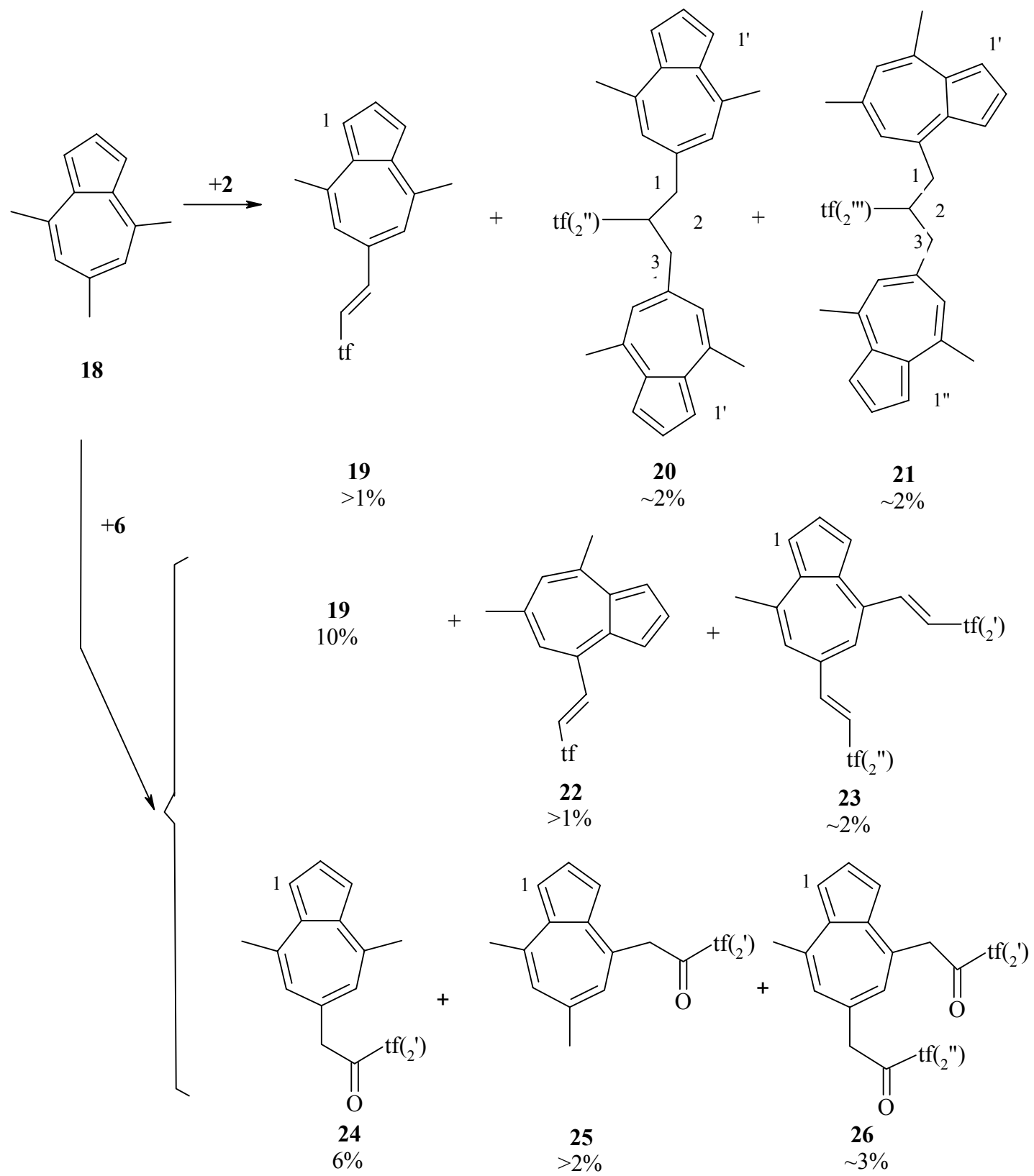

\section{Scheme 5}

\section{Heats of formation and energies of frontier molecular orbitals}

We have considered that some properties of the obtained ethylenes could be clarified by calculation of heats of formation and of the energies of frontier molecular orbitals. We were also interested from the perspective of using these compounds, as well as the isomers with vinyl group at $\mathrm{C} 1$ in azulene, ${ }^{1}$ as materials for NLO purposes. 
The calculated data, reported in Table 2, showed the higher stability of the isomer substituted at $\mathrm{C} 1$ as compared with all other isomers. Therefore this product possesses valuable features for technical purposes. In accord with traditional organic chromophore design guidelines, greater electron delocalization leads to enhanced NLO repose. This is also the case for the compound with the substituent at $\mathrm{C} 1$ for which $\mathrm{E}_{\mathrm{HOMO}}-\mathrm{E}_{\mathrm{LUMO}}=6.671 \mathrm{eV}$ followed by the compound substituted at $\mathrm{C} 4$ or at $\mathrm{C} 6(6.830 \mathrm{eV})$. The difference in intensity of push pull electronic effect for the compounds reported in Table 2 determines, as expected, some peculiarities of chemical shifts in the recorded NMR spectra as will be discussed below.

Table 2. Heats of formation and frontier molecular orbital energies of 2-(thien-2-yl)vinylazulenes $^{9}$

\begin{tabular}{lccccc}
\hline & \multicolumn{5}{c}{ Position of 2-(thien-2-yl)vinyl moiety on azulene } \\
\cline { 2 - 6 } & 1 & 2 & 4 & 5 & 6 \\
\hline$\Delta \mathrm{H}(\mathrm{Kcal} / \mathrm{mol})$ & 126.5 & 125.7 & 130.2 & 134.1 & 129.0 \\
$\mathrm{HOMO}(\mathrm{eV})$ & -7.682 & -8.069 & -7.972 & -7.842 & -7.984 \\
LUMO $(\mathrm{eV})$ & -1.011 & -1.159 & -1.142 & -0.978 & -1.154 \\
\hline
\end{tabular}

\section{NMR spectra}

Because of the very similar electronic demand of 2-thienyl and phenyl moieties the chemical shifts of the azulenyl groups in the studied compounds or in 1-(2-thien-2-ylvinyl)azulene are similar to those of corresponding styryl derivatives (Table 3). The ethylenic $\pi$ electrons, however, are more polarized in the latter compounds, thus $\delta\left(\left(\mathrm{C}_{\mathrm{Az}}\right)-H\right)-\delta\left(\left(\mathrm{C}_{\mathrm{Ph}}\right)-H\right)=0.52-0.73$ ppm whereas $\delta\left(\left(\mathrm{C}_{\mathrm{Az}}\right)-H\right)-\delta\left(\left(\mathrm{C}_{\mathrm{tf}}\right)-H\right)=0.20-0.32 \mathrm{ppm}$. It is apparent that the mobility of electronic system of the thienyl group is higher as compared to phenyl. Despite the similar value of the difference $\delta\left(\left(\mathrm{C}_{\mathrm{Az}}\right)-H\right)-\delta\left(\left(\mathrm{C}_{\mathrm{tf}}\right)-H\right)$ for the compounds substituted at $\mathrm{C} 4(\mathbf{4}, 11$ and 22) and for compound with the substituent at $\mathrm{C} 6(\mathbf{1 9})$ both alkenic protons of the compound 19 are shielded, with about $0.45 \mathrm{ppm}$. The different position of the methyl involved in the condensation changes the dihedral angle formed between the planes of ethylene and azulene. Therefore, the magnetic field anisotropy, generated by the azulene ring current is modified and this should explain the difference discussed above. 
Table 3. ${ }^{1} \mathrm{H}$ Chemical shifts for the compounds obtained here and corresponding reported ${ }^{5}$ styrylazulenes $^{\mathrm{a}}$

\begin{tabular}{|c|c|c|c|c|c|c|}
\hline \multicolumn{2}{|c|}{${ }^{1} \mathrm{H}$ Position } & \multicolumn{5}{|c|}{ Compounds $\delta$ (ppm) } \\
\hline & & \multirow{2}{*}{$\begin{array}{c}\mathbf{4} \\
\text { Me } 2.74 / \\
(2.73)\end{array}$} & \multirow{2}{*}{$\frac{11}{7.40}$} & \multirow{2}{*}{$\begin{array}{c}\mathbf{1 9} \\
\begin{array}{c}7.39 / \\
\mathrm{b}\end{array}\end{array}$} & \multirow{2}{*}{$\begin{array}{c}22 \\
7.43 / \\
(7.58)\end{array}$} & \multirow{2}{*}{$\begin{array}{c}1-\mathrm{tfC}=\mathrm{C}^{\mathrm{c}} \\
- \\
-\end{array}$} \\
\hline $\mathrm{Az}$ & 1 ' & & & & & \\
\hline & 2 ' & $\begin{array}{c}7.73 / \\
(7.72)\end{array}$ & 7.73 & $\begin{array}{c}7.70 / \\
(7.61)\end{array}$ & $\begin{array}{c}7.73 / \\
(7.71)\end{array}$ & $\begin{array}{c}8.17 / \\
(8.25)\end{array}$ \\
\hline & 3 , & $\begin{array}{c}7.52 / \\
(7.52)\end{array}$ & 7.56 & $\begin{array}{c}7.39 / \\
b\end{array}$ & $\begin{array}{c}7.60 / \\
(7.50)\end{array}$ & $\begin{array}{c}7.37 / \\
(7.40)\end{array}$ \\
\hline & 4 ' & - & - & $\begin{array}{c}\text { Me } 2.97 / \\
(2.88)\end{array}$ & - & $\begin{array}{l}8.16 / \\
(8.20)\end{array}$ \\
\hline & 5 & $\begin{array}{c}7.46 / \\
(7.45)\end{array}$ & 7.70 & $\begin{array}{c}7.34 / \\
(7.18)\end{array}$ & $\begin{array}{c}7.45 / \\
(7.48)\end{array}$ & $\begin{array}{c}7.05 / \\
(7.07)\end{array}$ \\
\hline & 6 & $\begin{array}{c}7.53 / \\
(7.54)\end{array}$ & - & - & $\begin{array}{l}(2.71) / \\
(2.72)\end{array}$ & $\begin{array}{c}7.50 / \\
(7.52)\end{array}$ \\
\hline & 7 & $i \operatorname{Pr} 3.14$ & 7.35 & $\begin{array}{c}7.34 \\
\mathrm{~b}\end{array}$ & $\begin{array}{c}7.10 / \\
(7.11)\end{array}$ & $\begin{array}{l}7.10 / \\
(7.11)\end{array}$ \\
\hline & 8 & $\begin{array}{c}8.23 / \\
(8.24)\end{array}$ & Me 2.95 & Me 2.97 & $\begin{array}{c}2.91 / \\
(2.91)\end{array}$ & $\begin{array}{l}8.41 / \\
(8.48)\end{array}$ \\
\hline Tf & $3 "$ & 7.23 & 7.22 & 7.19 & 7.23 & 7.07 \\
\hline & $4 "$ & 7.09 & 7.08 & 7.07 & 7.09 & 7.00 \\
\hline & $5 "$ & 7.32 & 7.31 & 7.29 & 7.32 & 7.15 \\
\hline $\mathrm{C}=\mathrm{C}$ & $\mathrm{C}_{\mathrm{Az}}$ & $\begin{array}{c}7.89 / \\
(8.06)\end{array}$ & 7.94 & $\begin{array}{c}7.46 \\
\mathrm{~b}\end{array}$ & $\begin{array}{c}7.91 / \\
(8.07)\end{array}$ & $\begin{array}{c}7.49 / \\
(7.71)\end{array}$ \\
\hline & $\mathrm{C}_{\mathrm{tf}}$ & $\begin{array}{c}7.57 / \\
(7.43) \\
\end{array}$ & 7.46 & $\underset{b}{7.11}$ & $\begin{array}{c}7.51 / \\
(7.34) \\
\end{array}$ & $\begin{array}{c}7.29 / \\
(7.19)\end{array}$ \\
\hline
\end{tabular}

${ }^{\mathrm{a}}$ The values in parenthesis are for the corresponding compounds with phenyl instead of 2-thienyl. ${ }^{\mathrm{b}}$ These signals are reported as multiplets between 7.30 and $7.20 \mathrm{ppm}$. ${ }^{\mathrm{c}}$ The chemical shifts for 1-(2-(thien-2-yl)vinyl)azulenes and for 1-styrylazulene were already reported. ${ }^{1}$

The change in $\delta$ of azulene protons when (2-(thien-2-yl)vinyl) is located at $\mathrm{C} 1$ as compared with the compound with this group at $\mathrm{C} 4$ or C6 is not evident due to the perturbing presence of the azulene alkyl groups. However, the deshielding of the thienyl protons in the last compounds proves a loss in conjugation between the two moieties connected to the double bond, as was already anticipated from the calculations.

It is interesting to note the prochirality of the methylene groups in the substituted propanes $\mathbf{5}$, 12, 20 and 21. Thus, a coupling constant of $\sim 13 \mathrm{~Hz}$ was found for the gem-methylene protons. The nonequivalence of the two protons depends, however, on the azulene substitution. 


\section{Conclusions}

The reaction between thiophene-2-carboxaldehyde or its azomethines and several azulenes with methyl groups on the seven-membered ring was investigated. The products obtained and the ratio in which they are formed depend on the nature of reagents used. Thus, starting from azomethines and guaiazulene, substituted alkenes and propanes were the main products, whereas the use of aldehyde generated carbonyl derivatives. When 2,8-dimethyl-6-tert-butylazulene was used, a higher amount of alkene resulted form the reaction with aldehyde. Due to the lower reactivity of 4,6,8-trimethylazulene the reaction occurred with low yields and the reaction mixture was more complex. In all the reactions studied, an amount of tar was formed, mainly for the last two azulenes. This behavior is somewhat different to that presented by benzalehyde and its azomethines in the comparable reactions. ${ }^{5,8}$ A structure assignment was accomplished for the most of the products. The correlation between some properties of 2-(thien-2-yl)vinyl-azulenes and their heats of formation and energies of frontier molecular orbitals as well as their ${ }^{1} \mathrm{H}-\mathrm{NMR}$ spectra are discussed briefly.

\section{Experimental Section}

General Procedures. Melting points: Kofler apparatus (Reichert Austria). Elemental analyses: COSTECH ECS 4010. ${ }^{1} \mathrm{H}$ - and ${ }^{13} \mathrm{C}-\mathrm{NMR}$ : Gemini $300\left({ }^{1} \mathrm{H}: 300 \mathrm{MHz},{ }^{13} \mathrm{C}: 75.45 \mathrm{MHz}\right)$ and Bruker Avance DRX4 $\left({ }^{1} \mathrm{H}: 400 \mathrm{MHz},{ }^{13} \mathrm{C}: 100.62 \mathrm{MHz}\right)$ spectrometers; chemical shifts $(\delta)$ are expressed in ppm, and $J$ values are given in $\mathrm{Hz}$; TMS was used as internal standard in $\mathrm{CDCl}_{3}$ as solvent; the signals were assigned on the basis of COSY and HETCOR experiments. Mass spectra: JEOL JMS-DX303 spectrometer coupled to analytical gas-chromatograph Shimadzu GC-14B with a DB-1 capillary column and C-R6A integrator; for the spectra recording in solid state Carlo Erba QMD 1000 (EI+, $70 \mathrm{eV})$. Column chromatography: silica gel [70-230 mesh (ASTM)]. Dichloromethane (DCM) was distilled over $\mathrm{CaH}_{2}$. UV spectra in hexane: Varian UVVis spectrometer Cary $100 \mathrm{BIO}$. The nomenclature was obtained by the use of ACD/I-Lab web service (ACD/IUPAC Name Free 7.06). The numberings of the atoms in the NMR spectra are indicated in the Schemes.

\section{General procedures for condensations}

A. Starting from imines. Under nitrogen, azulene $(1 \mathrm{mmol})$, imine $(1 \mathrm{mmol})$ and finely powder potassium hydroxide $(280 \mathrm{mg}, 5 \mathrm{mmol})$ were dissolved in DMF $(4 \mathrm{ml})$ with stirring at room temperature. The reaction mixture was stirred and heated at $60{ }^{\circ} \mathrm{C}$ for $30 \mathrm{~min}$ and then allowed to reach room temperature. DCM $(10 \mathrm{ml})$ and water $(20 \mathrm{ml})$ were added and the organic layer was separated. The remaining material in the aqueous layer was extracted twice with DCM $(2 \times 10$ $\mathrm{ml})$. The organic layer and the extracts were dried on sodium sulfate and the solvent was removed in vacuum. The compounds obtained were separated on silica gel column using hexane 
for elution. The unreacted hydrocarbon eluted firstly followed by alkenes (blue or green) and propanes. Several uncharacterized oligomers were also eluted from the column (blue or green). An amount of tar was not eluted.

B. Starting from aldehyde. Sodium $N$-methylanilide solution was prepared under nitrogen atmosphere using a mixture of sodium hydride $(200 \mathrm{mg}, 60 \%$ in mineral oil, $5.1 \mathrm{mmol})$ and $\mathrm{N}$ methylaniline $(1.81 \mathrm{~g}, 16.9 \mathrm{mmol})$ in THF $(10 \mathrm{ml})$ which was refluxed for $60 \mathrm{~min}$. To the solution obtained, cooled at room temperature, a solution of the azulene $(2.5 \mathrm{mmol})$ in THF (6 $\mathrm{ml})$ was added over a period of $15 \mathrm{~min}$, followed by thiophene-2-carboxaldehyde $(1.33 \mathrm{~g}, 1.11$ $\mathrm{ml}, 11.9 \mathrm{mmol}$ ) and the mixture was stirred overnight. THF was evaporated and DCM and water were added. The organic layer was separated and the aqueous layer was extracted twice with DCM. The organic layer and the extracts were dried on sodium sulfate and the solvent was removed in vacuum. The compounds obtained were separated on a silica gel column using hexane for elution. The unreacted hydrocarbon eluted firstly followed by alkenes (blue or green); the next fraction contained the ketones. Several uncharacterized oligomers were also eluted from the column (blue or green). An amount of tar was not eluted.

2-[(E)-2-(7-Isopropyl-1-methylazulen-4-yl)vinyl]thiophene (4). Green crystals, m.p. $87.5{ }^{\circ} \mathrm{C}$; UV (hexane, $\lambda(\mathrm{nm}) / \log (\varepsilon)$ ): 247 (4.23), 284 (4.53), 330 (4.41), 363 (4.33); ${ }^{1} \mathrm{H}-\mathrm{NMR}\left(\mathrm{CDCl}_{3}, \delta\right.$, ppm): $1.44\left(\mathrm{~d},{ }^{3} J=7.0 \mathrm{~Hz}, 6 \mathrm{H},\left(\mathrm{CH}_{3}\right)_{\mathrm{iPr}}\right), 2.74\left(\mathrm{~s}, 3 \mathrm{H}, \mathrm{Me}_{1}\right) 3.14$ (heptet, ${ }^{3} J=7.0 \mathrm{~Hz}, 1 \mathrm{H}$, $\left.\mathrm{CH}_{\mathrm{iPr}}\right), 7.09\left(\mathrm{dd},{ }^{3} J=5.0 \mathrm{~Hz},{ }^{3} J=3.6 \mathrm{~Hz}, 1 \mathrm{H}, 4^{\prime}-\mathrm{H}\right), 7.23\left(\mathrm{~d},{ }^{3} J=3.2 \mathrm{~Hz}, 1 \mathrm{H}, 3^{\prime}-\mathrm{H}\right), 7.32\left(\mathrm{~d},{ }^{3} J\right.$ $\left.=5.2 \mathrm{~Hz}, 1 \mathrm{H}, 5^{\prime}-\mathrm{H}\right), 7.46\left(\mathrm{~d}_{\mathrm{AB}},{ }^{3} J=11.1 \mathrm{~Hz}, 1 \mathrm{H}, 5-\mathrm{H}\right), 7.52\left(\mathrm{~d},{ }^{3} J=4.2 \mathrm{~Hz}, 1 \mathrm{H}, 3-\mathrm{H}\right), 7.53$ $\left(\mathrm{d}_{\mathrm{AB}}, \mathrm{d},{ }^{3} J=11.1 \mathrm{~Hz},{ }^{4} J=1.5 \mathrm{~Hz}, 1 \mathrm{H}, 6-\mathrm{H}\right), 7.57\left(\mathrm{~d}_{\mathrm{AB}},{ }^{3} J=15.8 \mathrm{~Hz}, 1 \mathrm{H},=\mathrm{CH}_{\mathrm{tf}}\right), 7.73\left(\mathrm{~d},{ }^{3} J=\right.$ $3.8 \mathrm{~Hz}, 1 \mathrm{H}, 2-\mathrm{H}), 7.89\left(\mathrm{~d}_{\mathrm{AB}},{ }^{3} J=15.9 \mathrm{~Hz}, 1 \mathrm{H},=\mathrm{CH}_{\mathrm{Az}}\right), 8.23\left(\mathrm{~d},{ }^{3} J=1.5 \mathrm{~Hz}, 1 \mathrm{H}, 8-\mathrm{H}\right) ;{ }^{13} \mathrm{C}-$ NMR $\left(\mathrm{CDCl}_{3}, \delta, \mathrm{ppm}\right): 13.02\left(\mathrm{Me}_{1}\right), 24.68\left(\left(\mathrm{CH}_{3}\right)_{\mathrm{iPr}}\right), 38.26\left(\mathrm{CH}_{\mathrm{iPr}}\right), 111.9(\mathrm{C} 3), 119.8(\mathrm{C} 5)$,

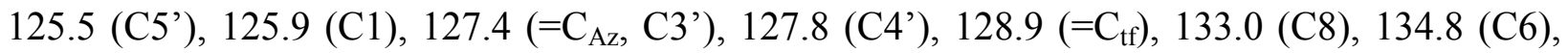
136.3 (C3a), 136.6 (C8a), 136.8 (C2), 140.0 (C7), 141.2 (C4), 142.8 (C2'); MS (ESI): 293 $[\mathrm{M}+1]$. Found C 82.09, H 6.96, S 10.95\% Calcd. for $\mathrm{C}_{20} \mathrm{H}_{20} \mathrm{~S}$ C 82.14, H 6.89, S 10.96\%

Bis 1,3-[1-methyl-7-isopropyl-azulen-4-yl]-2-(thien-2-yl)propane (5). Blue crystals, m.p. 114 ${ }^{\circ} \mathrm{C}$; UV (hexane, $\left.\lambda(\mathrm{nm}) / \log (\varepsilon)\right)$ : 244(4.90), 284(4.74), 349(3.85), 368(3.71), 612(2.70); ${ }^{1} \mathrm{H}-\mathrm{NMR}$ $\left(\mathrm{CDCl}_{3}, \delta, \mathrm{ppm}\right): 1.41\left(\mathrm{~d},{ }^{3} J=6.8 \mathrm{~Hz}, 12 \mathrm{H},\left(\mathrm{CH}_{3}\right)_{\mathrm{iPr}}\right), 2.71\left(\mathrm{~s}, 6 \mathrm{H}, \mathrm{Me}_{1}\right), 3.11$ (heptet, ${ }^{3} J=6.8$ $\left.\mathrm{Hz}, 2 \mathrm{H}, \mathrm{CH} \mathrm{iPr}_{\mathrm{Pr}}\right), 3.52\left(\mathrm{~d}_{\mathrm{AB}} \mathrm{d},{ }^{2} J=13.0 \mathrm{~Hz},{ }^{3} J=7.8 \mathrm{~Hz}, 2 \mathrm{H}, 1-\mathrm{H}_{\mathrm{a}}, 3-\mathrm{H}_{\mathrm{a}}\right), 3.72\left(\mathrm{~d}_{\mathrm{AB}} \mathrm{d},{ }^{2} J=13.0 \mathrm{~Hz}\right.$, ${ }^{3} J=7.8 \mathrm{~Hz}, 2 \mathrm{H}, 1-\mathrm{H}_{\mathrm{b}}, 3-\mathrm{H}_{\mathrm{b}}$ ), 4.22 (quintet, $\left.{ }^{3} J=7.8 \mathrm{~Hz}, 1 \mathrm{H}, 2-\mathrm{H}\right), 6.60$ (dd, ${ }^{3} J=3.5 \mathrm{~Hz},{ }^{4} J=1.3$ $\mathrm{Hz}, 1 \mathrm{H}, 3$ "'-H), 6.84 (dd, ${ }^{3} J=5.1 \mathrm{~Hz},{ }^{4} J=3.5 \mathrm{~Hz}, 1 \mathrm{H}, 4$ "'-H), $6.90\left(\mathrm{~d}_{\mathrm{AB}},{ }^{3} J=10.7 \mathrm{~Hz}, 2 \mathrm{H}, 5\right.$ ' H), $7.02\left(\mathrm{~d},{ }^{3} J=3.8 \mathrm{~Hz}, 2 \mathrm{H}, 3^{3}-\mathrm{H}\right), 7.18\left(\mathrm{dd},{ }^{3} J=5.1 \mathrm{~Hz},{ }^{4} J=1.3 \mathrm{~Hz}, 1 \mathrm{H}, 5^{\prime}\right.$ '-H), $7.35\left(\mathrm{~d}_{\mathrm{AB}},{ }^{3} J\right.$ $\left.=10.7 \mathrm{~Hz},{ }^{4} \mathrm{~J}=1.3 \mathrm{~Hz}, 2 \mathrm{H}, 6{ }^{\prime}-\mathrm{H}\right), 7.59\left(\mathrm{~d},{ }^{3} \mathrm{~J}=3.9 \mathrm{~Hz}, 2 \mathrm{H}, 2^{\prime}-\mathrm{H}\right), 8.23\left(\mathrm{~d},{ }^{4} \mathrm{~J}=1.9 \mathrm{~Hz}, 2 \mathrm{H}, 8^{\prime}-\right.$ $\mathrm{H}) ;{ }^{13} \mathrm{C}-\mathrm{NMR}\left(\mathrm{CDCl}_{3}, \delta, \mathrm{ppm}\right): 12.92(\mathrm{Me}), 24.69\left(\left(\mathrm{CH}_{3}\right)_{\mathrm{iPr}}\right), 38.16\left(\mathrm{CH}_{\mathrm{iPr}}\right), 44.26(\mathrm{C} 2), 46.24$ (C1, C3), 112.3 (C3'), 122.9 (C5”), 124.4 (C3”), 125.0 (C1', C5'), 126.3 (C4”), 133.2 (C8'), 134.6 (C6'), 136.2 (C3'a), 136.5 (C2'), 137.5 (C8'a), 139.9 (C7'), 146.0 (C4'), 148.8 (C2’'); MS (ESI): 491 [M+1]. Found C 85.53, H 7.92, S 6.55\% Calcd. for $\mathrm{C}_{35} \mathrm{H}_{38} \mathrm{~S}$ C 85.66, H 7.80, S 6.53\% 
2-(7-Isopropyl-1-methylazulen-4-yl)-1-thien-2-ylethanone (8). Green crystals, m.p. $106{ }^{\circ} \mathrm{C}$; UV (hexane, $\lambda(\mathrm{nm}) / \log (\varepsilon)$ ): 251 (4.55), 285 (4.68), 350 (3.68), 368 (3.55), 610 (2.49); ${ }^{1} \mathrm{H}-\mathrm{NMR}$ $\left(\mathrm{CDCl}_{3}, \delta, \mathrm{ppm}\right): 1.40\left(\mathrm{~d},{ }^{3} J=6.8 \mathrm{~Hz}, 6 \mathrm{H},\left(\mathrm{CH}_{3}\right)_{\mathrm{iPr}}\right), 2.70(\mathrm{~s}, 3 \mathrm{H}, 1-\mathrm{Me}), 3.12$ (heptet, ${ }^{3} J=6.8$ $\left.\mathrm{Hz}, 1 \mathrm{H}, \mathrm{CH} \mathrm{iPr}_{\mathrm{r}}\right), 4.73\left(\mathrm{~s}, 2 \mathrm{H}, \mathrm{CH}_{2}\right), 7.08\left(\mathrm{dd},{ }^{3} J=4.9 \mathrm{~Hz},{ }^{3} \mathrm{~J}=3.9 \mathrm{~Hz}, 1 \mathrm{H}, 4^{\prime}-\mathrm{H}\right), 7.10\left(\mathrm{~d},{ }^{3} J=\right.$ $10.6 \mathrm{~Hz}, 1 \mathrm{H}, 5-\mathrm{H}), 7.32\left(\mathrm{~d},{ }^{3} J=3.9 \mathrm{~Hz}, 1 \mathrm{H}, 3-\mathrm{H}\right), 7.48\left(\mathrm{dd},{ }^{3} J=10.6 \mathrm{~Hz},{ }^{4} J=1.9 \mathrm{~Hz}, 1 \mathrm{H}, 6-\right.$ H), $7.62\left(\mathrm{dd},{ }^{3} J=4.9 \mathrm{~Hz},{ }^{4} J=1.1 \mathrm{~Hz}, 1 \mathrm{H}, 5^{\prime}-\mathrm{H}\right), 7.70\left(\mathrm{~d},{ }^{3} J=3.8 \mathrm{~Hz}, 1 \mathrm{H}, 2-\mathrm{H}\right), 7.85\left(\mathrm{dd},{ }^{3} J=\right.$ $3.8 \mathrm{~Hz},{ }^{4} J=1.1 \mathrm{~Hz}, 1 \mathrm{H}, 3$ '-H), $8.25\left(\mathrm{~d},{ }^{3} J=1.8 \mathrm{~Hz}, 1 \mathrm{H}, 8-\mathrm{H}\right) ;{ }^{13} \mathrm{C}-\mathrm{NMR}\left(\mathrm{CDCl}_{3}, \delta, \mathrm{ppm}\right)$ : $13.25\left(\mathrm{Me}_{1}\right), 25.00\left(\left(\mathrm{CH}_{3}\right)_{\mathrm{iPr}}\right), 38.60\left(\mathrm{CH}_{\mathrm{iPr}}\right), 48.30\left(\mathrm{CH}_{2}\right), 113.1(\mathrm{CH}), 125.2(\mathrm{CH}), 126.2(\mathrm{Cq})$, $128.5(\mathrm{CH}), 132.7(\mathrm{CH}), 134.0(\mathrm{CH}), 134.3(\mathrm{CH}), 135.2(\mathrm{CH}), 137.3(\mathrm{Cq}), 137.6(\mathrm{CH}), 137.8$ $(\mathrm{Cq}), 140.1(\mathrm{Cq}), 141.1(\mathrm{Cq}), 144.4(\mathrm{Cq}), 190.4(\mathrm{CO})$; MS (ESI): 309 [M+1]. Found C 77.80, H 6.62, S $10.45 \%$ Calcd. for $\mathrm{C}_{20} \mathrm{H}_{20} \mathrm{SO} \mathrm{C} 77.88$, H 6.54, S $10.41 \%$

2-(7-Isopropyl-1-methylazulen-4-yl)-1,3-di(thien-2-yl)prop-2-en-1-one (9). Green oil; ${ }^{1} \mathrm{H}$ $\operatorname{NMR}\left(\mathrm{CDCl}_{3}, \delta, \mathrm{ppm}\right): 1.46\left(\mathrm{~d},{ }^{3} J=6.9 \mathrm{~Hz}, 6 \mathrm{H},\left(\mathrm{CH}_{3}\right)_{\mathrm{iPr}}\right), 2.71$ (s, $\left.3 \mathrm{H}, \mathrm{Me}_{1}\right), 3.19$ (heptet, ${ }^{3} J=$ $\left.6.9 \mathrm{~Hz}, 1 \mathrm{H}, \mathrm{CH} H_{\mathrm{iPr}}\right), 6.88\left(\mathrm{dd},{ }^{3} J=5.1 \mathrm{~Hz},{ }^{3} J=3.7 \mathrm{~Hz}, 1 \mathrm{H}, 4{ }^{\prime}-\mathrm{H}\right), 6.95\left(\mathrm{dd},{ }^{3} J=5.0 \mathrm{~Hz},{ }^{4} J=3.8\right.$ $\mathrm{Hz}, 1 \mathrm{H}, 4$ "'-H), $7.11\left(\mathrm{~d},{ }^{3} \mathrm{~J}=10.4 \mathrm{~Hz}, 1 \mathrm{H}, 5-\mathrm{H}\right), 7.14\left(\mathrm{dd},{ }^{3} J=5.0 \mathrm{~Hz},{ }^{4} \mathrm{~J}=1.3 \mathrm{~Hz}, 1 \mathrm{H}, 5^{\prime}-\mathrm{H}\right)$, 7,19 (ddd, ${ }^{3} J=3.6,{ }^{4} J=1.2 \mathrm{~Hz},{ }^{4} J=0.6 \mathrm{~Hz}, 1 \mathrm{H}, 3$ '-H), 7.21 (d, $\left.{ }^{3} J=3.8 \mathrm{~Hz}, 1 \mathrm{H}, 3-\mathrm{H}\right), 7.49$ (dd, ${ }^{3} J=3.9 \mathrm{~Hz},{ }^{4} J=1.2 \mathrm{~Hz}, 1 \mathrm{H}, 3$ "'-H), $7.52\left(\mathrm{dd},{ }^{3} J=5.0 \mathrm{~Hz},{ }^{4} J=1.1 \mathrm{~Hz}, 1 \mathrm{H}, 5\right.$ "'-H), $7.56\left(\mathrm{dd},{ }^{3} J=\right.$ $\left.10.8 \mathrm{~Hz},{ }^{4} \mathrm{~J}=1.9 \mathrm{~Hz}, 1 \mathrm{H}, 6-\mathrm{H}\right), 7.62\left(\mathrm{~d},{ }^{3} \mathrm{~J}=3.8 \mathrm{~Hz}, 2 \mathrm{H}, 2-\mathrm{H}\right), 8.17$ (s, $\left.1 \mathrm{H}, \mathrm{CH}=\right), 8.32\left(\mathrm{~d},{ }^{4} \mathrm{~J}=\right.$ $1.7 \mathrm{~Hz}, 1 \mathrm{H}, 8-\mathrm{H}) ;{ }^{13} \mathrm{C}-\mathrm{NMR}\left(\mathrm{CDCl}_{3}, \delta\right.$, ppm): $13.29\left(\mathrm{Me}_{1}\right), 25.11\left(\left(\mathrm{CH}_{3}\right)_{\mathrm{iPr}}\right), 38.85\left(\mathrm{CH}_{\mathrm{iPr}}\right), 114.5$ $(\mathrm{CH}), 125.2(\mathrm{CH}), 126.4(\mathrm{Cq}), 126.8(\mathrm{CH}), 128.0(\mathrm{CH}), 129.1(\mathrm{CH}), 131.2(\mathrm{CH}), 131.6(\mathrm{CH})$, $132.8(\mathrm{Cq}), 133.6(\mathrm{CH}), 133.9(\mathrm{CH}), 134.0(\mathrm{CH}), 135.9(\mathrm{CH}), 136.8(\mathrm{Cq}), 138.3(\mathrm{Cq}), 138.5$ $(\mathrm{Cq}), 138.8(\mathrm{CH}), 144.3(\mathrm{Cq}), 141.8(\mathrm{Cq}), 142.0(\mathrm{Cq}), 185.4(\mathrm{CO})$; MS (ESI): 403 [M+1]. Found C 74.55, H 5.62, S 15.89\% Calcd. for $\mathrm{C}_{25} \mathrm{H}_{22} \mathrm{~S}_{2} \mathrm{O}$ C 74.59, H 5.51, S $15.93 \%$

2-[(E)-2-(8-Methyl-6-tert-butylazulen-4-yl)vinyl]thiophene (11). Blue crystals, m.p. $119.5{ }^{\circ} \mathrm{C}$; UV (hexane, $\lambda(\mathrm{nm}) / \log (\varepsilon)$ ): 247 (4.21), 287 (4.52), 314 (4.39), 566 (2.68); ${ }^{1} \mathrm{H}-\mathrm{NMR}\left(\mathrm{CDCl}_{3}, \delta\right.$, ppm): 1.53 (s, $9 \mathrm{H}, t$-Bu), 2.95 (s, $\left.3 \mathrm{H}, \mathrm{Me}_{8}\right), 7.08$ (dd, $\left.{ }^{3} J=5.0 \mathrm{~Hz},{ }^{4} J=3.5 \mathrm{~Hz}, 1 \mathrm{H}, 4^{\prime}-\mathrm{H}\right), 7.22$ $\left(\mathrm{dd},{ }^{3} J=3.6 \mathrm{~Hz},{ }^{4} J=0.6 \mathrm{~Hz}, 1 \mathrm{H}, 3^{\prime}-\mathrm{H}\right), 7.31\left(\mathrm{~d},{ }^{3} J=5.0 \mathrm{~Hz}, 1 \mathrm{H}, 5^{\prime}-\mathrm{H}\right), 7.35$ (s, $\left.1 \mathrm{H}, 7-\mathrm{H}\right), 7.40$ $\left(\mathrm{dd},{ }^{3} J=3.7 \mathrm{~Hz},{ }^{4} J=1.3 \mathrm{~Hz}, 1 \mathrm{H}, 1-\mathrm{H}\right), 7.46\left(\mathrm{~d}_{\mathrm{AB}},{ }^{3} J=15.8 \mathrm{~Hz}, 1 \mathrm{H},=\mathrm{CH}_{\mathrm{tf}}\right), 7.56\left(\mathrm{dd},{ }^{3} J=4.1\right.$ $\left.\mathrm{Hz},{ }^{4} \mathrm{~J}=1.4 \mathrm{~Hz}, 1 \mathrm{H}, 3-\mathrm{H}\right), 7.70\left(\mathrm{~d},{ }^{4} \mathrm{~J}=1.5 \mathrm{~Hz}, 1 \mathrm{H}, 5-\mathrm{H}\right), 7.73\left(\mathrm{t},{ }^{3} \mathrm{~J}=3.9 \mathrm{~Hz}, 1 \mathrm{H}, 2-\mathrm{H}\right), 7.94$ $\left(\mathrm{d},{ }^{3} \mathrm{~J}=15.9 \mathrm{~Hz}, 1 \mathrm{H},=\mathrm{CH}_{\mathrm{Az}}\right) ;{ }^{13} \mathrm{C}-\mathrm{NMR}\left(\mathrm{CDCl}_{3}, \delta, \mathrm{ppm}\right): 26.22\left(\mathrm{Me}_{8}\right), 32.54\left(\mathrm{Me}_{\mathrm{tBu}}\right), 39.38$ $\left(\mathrm{C}_{\mathrm{tBu}}\right), 115.3$ (C3), 116.7 (C1), 119.1 (C5), 124.5 (C7), 125.8 (C5'), $127.2\left(\mathrm{C}_{\mathrm{tf}}\right), 127.7$ (C3'), 128.1 (C4'), $131.1\left(\mathrm{C}_{\mathrm{Az}}\right), 133.8(\mathrm{C} 2), 135.9(\mathrm{Cq}), 137.1(\mathrm{Cq}), 142.9(\mathrm{Cq}), 143.2(\mathrm{C} 4), 145.5$ (Cq), $158.3(\mathrm{Cq})$; MS-ESI: 307 [M+1]. Found C 82.24, H 7.35, S 10.41\% Calcd. for $\mathrm{C}_{21} \mathrm{H}_{22} \mathrm{~S} \mathrm{C}$ $82.30, \mathrm{H} 7.24, \mathrm{~S} 10.46 \%$

Bis 1,3-[8-methyl-6-tert-butylazulen-4-yl]-2-(thien-2-yl)propane (12). Violet oil; ${ }^{1} \mathrm{H}-\mathrm{NMR}$ $\left(\mathrm{CDCl}_{3}, \delta, \mathrm{ppm}\right): 1,36(\mathrm{~s}, 18 \mathrm{H}, t-\mathrm{Bu}), 2.95\left(\mathrm{~s}, 6 \mathrm{H}, \mathrm{Me}_{8}\right), 3.49\left(\mathrm{dd},{ }^{2} J=12.8 \mathrm{~Hz},{ }^{3} J=8.4 \mathrm{~Hz}, 2\right.$ $\left.\mathrm{H}, 1-\mathrm{H}_{\mathrm{a}}, 3-\mathrm{H}_{\mathrm{a}}\right), 3.91\left(\mathrm{dd},{ }^{2} J=12.8 \mathrm{~Hz},{ }^{3} J=8.2 \mathrm{~Hz}, 2 \mathrm{H}, 1-\mathrm{H}_{\mathrm{b}}, 3-\mathrm{H}_{\mathrm{b}}\right), 4.10-4.22(\mathrm{~m}, 1 \mathrm{H}, 2-\mathrm{H})$, $6.43\left(\mathrm{dd},{ }^{3} J=3.5 \mathrm{~Hz},{ }^{4} \mathrm{~J}=1.3 \mathrm{~Hz}, 1 \mathrm{H}, 3\right.$ "'-H), $6.77\left(\mathrm{dd},{ }^{3} J=5.1 \mathrm{~Hz},{ }^{4} J=3.4 \mathrm{~Hz}, 1 \mathrm{H}, 4{ }^{\prime}-\mathrm{H}\right)$, $7.10\left(\mathrm{dd},{ }^{3} J=4.1 \mathrm{~Hz},{ }^{4} \mathrm{~J}=1.6 \mathrm{~Hz}, 2 \mathrm{H}, 3^{\prime}-\mathrm{H}\right), 7.16\left(\mathrm{dd},{ }^{3} J=5.1 \mathrm{~Hz},{ }^{4} \mathrm{~J}=1.2 \mathrm{~Hz}, 1 \mathrm{H}, 5\right.$ '-H), 7.17 $\left(\mathrm{d},{ }^{4} J=1.8 \mathrm{~Hz}, 2 \mathrm{H}, 7{ }^{\prime}-\mathrm{H}\right), 7.30\left(\mathrm{~d},{ }^{4} J=1.6 \mathrm{~Hz}, 2 \mathrm{H}, 5^{\prime}-\mathrm{H}\right), 7.34\left(\mathrm{dd},{ }^{3} J=3.9 \mathrm{~Hz},{ }^{4} J=1.6 \mathrm{~Hz}, 2\right.$ 
H, 1'-H), $7.62\left(\mathrm{t},{ }^{4} J=4.0 \mathrm{~Hz}, 2 \mathrm{H}, 2{ }^{\prime}-\mathrm{H}\right) ;{ }^{13} \mathrm{C}-\mathrm{NMR}\left(\mathrm{CDCl}_{3}, \delta, \mathrm{ppm}\right): 26.22\left(\mathrm{Me}_{8}\right), 32.34$ $\left(\mathrm{Me}_{\mathrm{tBu}}\right), 38.93\left(\mathrm{C}_{\mathrm{tBu}}\right), 45.94(\mathrm{CH}), 48.46\left(\mathrm{CH}_{2}\right), 115.4(\mathrm{CH}), 115.9(\mathrm{CH}), 123.5(\mathrm{CH}), 124.3$ $(\mathrm{CH}), 124.5(\mathrm{CH}), 125.3(\mathrm{CH}), 126.8(\mathrm{CH}), 133.7(\mathrm{CH}), 136.7(\mathrm{Cq}), 136.8(\mathrm{Cq}), 145.4(\mathrm{Cq})$, 147,2 (Cq), 149,0 (Cq), 158,2 (Cq); MS (ESI): 519 [M+1]. Found C 85.57, H 8.24, S 6.19\% Calcd. for $\mathrm{C}_{37} \mathrm{H}_{42} \mathrm{~S}$ C 85.66, H 8.16, S 6.18\%

4,8-Bis[3-(8-methyl-6-tert-butylazulen-4-yl)-2(thien-2-yl)propil]-6-tert-butylazulene (13). (Mixture of diastereoisomers). Green crystals, m.p. $139{ }^{\circ} \mathrm{C} ;{ }^{1} \mathrm{H}-\mathrm{NMR}\left(\mathrm{CDCl}_{3}, \delta, \mathrm{ppm}\right):{ }^{10} 1.23$ (s, $18 \mathrm{H}, t-\mathrm{Bu}), 1.38\left(\mathrm{~s}, 9 \mathrm{H}, t-\mathrm{Bu}\right.$ '), $2.96(\mathrm{~s}, 6 \mathrm{H}, \mathrm{Me}), 3.39-3.52\left(\mathrm{~m}, 4 \mathrm{H}, 1-\mathrm{H}_{\mathrm{a}}, 3-\mathrm{H}_{\mathrm{a}}\right), 3.83-3.92(\mathrm{~m}$, $\left.4 \mathrm{H}, 1-\mathrm{H}_{\mathrm{b}}, 3-\mathrm{H}_{\mathrm{b}}\right), 4.17$ (bs, $\left.2 \mathrm{H}, 2-\mathrm{H}\right), 6.40$ (d, ${ }^{3} \mathrm{~J}=5.5 \mathrm{~Hz}, 2 \mathrm{H}, 3$ '"'-H), 6.73-6.78 (m, 2 H, 4"'$\mathrm{H})$, 7.03-7.15 (m, 8 H, $\left.2 \mathrm{H}_{\mathrm{tf}}, 6 \mathrm{H}_{\mathrm{Az}}\right), 7.19$ (s, $2 \mathrm{H}, 5$ "'-H), 7.31 (s, $2 \mathrm{H}, 7$ '”-H), 7.33-7.35 (m, 2 H, $\left.\mathrm{H}_{\mathrm{Az}}\right), 7.50\left(\mathrm{~m}, 1 \mathrm{H}, \mathrm{H}_{\mathrm{Az}}\right), 7.58\left(\mathrm{~m}, 1-\mathrm{H}, \mathrm{H}_{\mathrm{Az}}\right), 7.62\left(\mathrm{~m}, 1-\mathrm{H}, \mathrm{H}_{\mathrm{Az}}\right)$; MS (ESI): 825 [M+1]. Found C 84.35, H 7.91, S 7.74\% Calcd. for $\mathrm{C}_{58} \mathrm{H}_{64} \mathrm{~S}$ C 84.41, H 7.82, S 7.77\%

Bis4,8-\{2-[(E)-thien-2-yl]vinyl\}-6-tert-butylazulene (14). Green oil. UV (hexane, $\lambda$ $(\mathrm{nm}) / \log (\varepsilon)): 287$ (4.53), 350 (4.88), 623 (2.96); ${ }^{1} \mathrm{H}-\mathrm{NMR}\left(\mathrm{CDCl}_{3}, \delta, \mathrm{ppm}\right): 1.61$ (s, $9 \mathrm{H}, t$-Bu), $7.10\left(\mathrm{dd},{ }^{3} J=5.0 \mathrm{~Hz},{ }^{3} J=3.7 \mathrm{~Hz}, 2 \mathrm{H}, 4^{\prime}-\mathrm{H}\right), 7.25\left(\mathrm{~d},{ }^{3} J=3.3 \mathrm{~Hz}, 2 \mathrm{H}, 3^{\prime}-\mathrm{H}\right), 7.33$ (d, ${ }^{3} J=5.1$ $\left.\mathrm{Hz}, 2 \mathrm{H}, 5^{\prime}-\mathrm{H}\right), 7.50\left(\mathrm{~d},{ }^{3} \mathrm{~J}=15.9 \mathrm{~Hz}, 2 \mathrm{H},=\mathrm{CH}_{\mathrm{tf}}\right), 7.62\left(\mathrm{~d},{ }^{3} \mathrm{~J}=3.9 \mathrm{~Hz}, 2 \mathrm{H}, 1-\mathrm{H}, 3-\mathrm{H}\right), 7.75(\mathrm{~s}, 2$ $\mathrm{H}, 5-\mathrm{H}, 7-\mathrm{H}), 7.79\left(\mathrm{t},{ }^{3} \mathrm{~J}=3.7 \mathrm{~Hz}, 1 \mathrm{H}, 2-\mathrm{H}\right), 7.95\left(\mathrm{~d},{ }^{3} \mathrm{~J}=15.9 \mathrm{~Hz}, 2 \mathrm{H},=\mathrm{CH}_{\mathrm{Az}}\right) ;{ }^{13} \mathrm{C}-\mathrm{NMR}$ $\left(\mathrm{CDCl}_{3}, \delta, \mathrm{ppm}\right): 32.59\left(\mathrm{Me}_{\mathrm{tBu}}\right), 39.72\left(\mathrm{C}_{\mathrm{tBu}}\right), 116.1$ (C1, C3), 119.7 (C5, C7), $125.9(\mathrm{C} 5$ '), 127.3 $\left(=\mathrm{C}_{\mathrm{Az}}\right), 127.8\left(\mathrm{C}^{\prime}\right), 128.1\left(\mathrm{C}^{\prime}\right), 131.1\left(=\mathrm{C}_{\mathrm{tf}}\right), 134.1(\mathrm{C} 2), 136.3(\mathrm{Cq}), 142.9(\mathrm{Cq}), 143.1(\mathrm{Cq})$, 157.9(Cq); MS (ESI): 401 [M+1]. Found C 77.93, H 6.11, S 15.96\% Calcd. for $\mathrm{C}_{26} \mathrm{H}_{24} \mathrm{~S}$ C 77.95, H 6.04, S $16.01 \%$

2-(6-Tertbutyl-8-methylazulen-4-yl)-1-thien-2-ylethanone (15). Violet oil; UV (hexane, $\lambda$ $(\mathrm{nm}) / \log (\varepsilon)): 247$ (4.37), 285 (4.53), 348 (3.44), 551 (2.48); ${ }^{1} \mathrm{H}-\mathrm{NMR}\left(\mathrm{CDCl}_{3}, \delta, \mathrm{ppm}\right): 1.49$ (s, 9 $\mathrm{H}, t$-Bu), $2.99\left(\mathrm{~s}, 3 \mathrm{H}, \mathrm{Me}_{8}\right), 4.85\left(\mathrm{~s}, 2 \mathrm{H}, \mathrm{CH}_{2}\right), 7.10\left(\mathrm{dd},{ }^{3} J=4.9 \mathrm{~Hz},{ }^{3} J=3.8 \mathrm{~Hz}, 1 \mathrm{H}, 4{ }^{\prime}-\mathrm{H}\right)$, 7.42 (s, $1 \mathrm{H}, 7-\mathrm{H}), 7.44\left(\mathrm{dd},{ }^{3} J=4.1 \mathrm{~Hz},{ }^{4} J=1.4 \mathrm{~Hz}, 1 \mathrm{H}, 1-\mathrm{H}\right), 7.45$ (s, $\left.1 \mathrm{H}, 5-\mathrm{H}\right), 7.46$ (dd, ${ }^{3} J=$ $\left.4.4 \mathrm{~Hz},{ }^{4} \mathrm{~J}=1.4 \mathrm{~Hz}, 1 \mathrm{H}, 3-\mathrm{H}\right), 7.63\left(\mathrm{dd},{ }^{3} \mathrm{~J}=4.8 \mathrm{~Hz},{ }^{4} \mathrm{~J}=1.1 \mathrm{~Hz}, 1 \mathrm{H}, 5\right.$ '-H), $7.78\left(\mathrm{t},{ }^{3} \mathrm{~J}=4.9 \mathrm{~Hz}\right.$, $1 \mathrm{H}, 2-\mathrm{H}), 7.86\left(\mathrm{dd},{ }^{3} J=3.8 \mathrm{~Hz},{ }^{4} J=1.2 \mathrm{~Hz}, 1 \mathrm{H}, 3{ }^{\prime}-\mathrm{H}\right) ;{ }^{1} \mathrm{C}-\mathrm{NMR}\left(\mathrm{CDCl}_{3}, \delta, \mathrm{ppm}\right): 26.11$ $\left(\mathrm{Me}_{8}\right), 32.31\left(\mathrm{Me}_{\mathrm{tBu}}\right), 39.09\left(\mathrm{C}_{\mathrm{tBu}}\right), 49.55\left(\mathrm{CH}_{2}\right), 115.8(\mathrm{C} 3), 116.6(\mathrm{C} 1), 124.3(\mathrm{C} 5), 124.8(\mathrm{C} 7)$, 128.1 (C5'), 132.7 (C2), 134.2 (C4'), 134.4 (C3'), 136.8 (Cq), 137.2 (Cq), 141.1 (Cq), 144.3 (Cq), $145.9(\mathrm{Cq}), 158.5(\mathrm{Cq}), 190.5(\mathrm{CO})$; MS (ESI): 323 [M+1]. Found C 78.13, H 6.95, S 9.99\% Calcd. for $\mathrm{C}_{58} \mathrm{H}_{64} \mathrm{~S}$ C 78.22, H 6.88, S 9.94\%

2-(6-tert-Butyl-8-methylazulen-4-yl)-1,3-dithien-2-ylprop-2-en-1-one (16). Violet oil; ${ }^{11}{ }^{1} \mathrm{H}$ NMR ( $\left.\mathrm{CDCl}_{3}, \delta, \mathrm{ppm}\right): 1.43(\mathrm{~s}, 9 \mathrm{H}, t-\mathrm{Bu}), 3.03$ (s, $\left.3 \mathrm{H}, \mathrm{Me}_{8}\right), 6.86\left(\mathrm{dd},{ }^{3} J=4.9 \mathrm{~Hz},{ }^{3} J=3.9 \mathrm{~Hz}\right.$, $\left.1 \mathrm{H}, 4^{\prime}-\mathrm{H}\right), 6.91\left(\mathrm{dd},{ }^{3} J=4.9 \mathrm{~Hz},{ }^{3} J=3.9 \mathrm{~Hz}, 1 \mathrm{H}, 4{ }^{\prime}{ }^{-H}\right), 7.12\left(\mathrm{~d},{ }^{3} J=5.0 \mathrm{~Hz}, 1 \mathrm{H}, 5\right.$ '-H), 7.20 $\left(\mathrm{d},{ }^{3} J=3.7 \mathrm{~Hz}, 1 \mathrm{H}, 3^{\prime}-\mathrm{H}\right), 7.27$ (d, $\left.{ }^{3} J=3.9 \mathrm{~Hz}, 1 \mathrm{H}, 1-\mathrm{H}\right), 7.28\left(\mathrm{~d},{ }^{3} J=3.7 \mathrm{~Hz}, 1 \mathrm{H}, 3-\mathrm{H}\right), 7.40$ $\left(\mathrm{d},{ }^{3} J=3.7 \mathrm{~Hz}, 1 \mathrm{H}, 3\right.$ "'-H), 7.46 (s, $\left.1 \mathrm{H}, 7-\mathrm{H}\right), 7.48$ (d, ${ }^{3} J=4.9 \mathrm{~Hz}, 1 \mathrm{H}, 5$ "-H), 7.48 (s, $1 \mathrm{H}, 5-$ H), $7.64\left(\mathrm{t},{ }^{3} J=3.8 \mathrm{~Hz}, 1 \mathrm{H}, 2-\mathrm{H}\right), 8.20$ (s, $\left.1 \mathrm{H}, \mathrm{CH}=\right)$; MS (ESI): 417 [M+1].

2-[(E)-2-(4.8-Dimethylazulen-6-yl)vinyl]thiophene (19). Green crystals, m.p. $125{ }^{\circ} \mathrm{C}$; UV (hexane, $\lambda(\mathrm{nm}) / \log (\varepsilon)): 244$ (4.19), 274 (4.20), 331(4.59), 400 (4.42), 607 (2.43); ${ }^{1} \mathrm{H}-\mathrm{NMR}$ $\left(\mathrm{CDCl}_{3}, \delta, \mathrm{ppm}\right): 2.97$ (s, $6 \mathrm{H}, \mathrm{Me}_{4}$ si $\left.\mathrm{Me}_{8}\right), 7.07\left(\mathrm{dd},{ }^{3} J=5.0 \mathrm{~Hz},{ }^{4} J=3.6 \mathrm{~Hz}, 1 \mathrm{H}, 4^{\prime}-\mathrm{H}\right), 7.11$ 
$\left(\mathrm{d},{ }^{3} \mathrm{~J}=16.0 \mathrm{~Hz}, 1 \mathrm{H},=\mathrm{CH}_{\mathrm{tf}}\right), 7.19\left(\mathrm{dd},{ }^{3} J=3.6 \mathrm{~Hz},{ }^{4} J=1.3 \mathrm{~Hz}, 1 \mathrm{H}, 3{ }^{\prime}-\mathrm{H}\right), 7.29\left(\mathrm{dd},{ }^{3} J=5.1\right.$ $\mathrm{Hz},{ }^{4} J=1.3 \mathrm{~Hz}, 1 \mathrm{H}, 5$ '-H), 7.34 (s, $\left.2 \mathrm{H}, 5-\mathrm{H}, 7-\mathrm{H}\right), 7.39$ (d, $\left.{ }^{3} J=3.8 \mathrm{~Hz}, 2 \mathrm{H}, 1-\mathrm{H}, 3-\mathrm{H}\right), 7.46$ (d, $\left.{ }^{3} J=16.0 \mathrm{~Hz}, 1 \mathrm{H},=\mathrm{CH}_{\mathrm{Az}}\right), 7.70\left(\mathrm{t},{ }^{3} J=3.9 \mathrm{~Hz}, 1 \mathrm{H}, 2-\mathrm{H}\right) ;{ }^{13} \mathrm{C}-\mathrm{NMR}\left(\mathrm{CDCl}_{3}, \delta, \mathrm{ppm}\right): 25.67$ $\left(\mathrm{Me}_{4}, \mathrm{Me}_{8}\right), 116.9$ (C1, C3), 124.5 (C5, C7), 125.4 (C5'), 125.8(=C $\left.\mathrm{C}_{\mathrm{tf}}\right), 127.8$ (C3'), 128.2 (C4'), $133.6\left(=\mathrm{C}_{\mathrm{Az}}\right), 133.8(\mathrm{C} 2), 137.0$ (C3a, C8a), 142.9 (C2'), 143.3 (C6), 145.6 (C4, C8); MS (ESI): 265 [M+1]. Found C 81.69, H 6.16, S 12.15\% Calcd. for $\mathrm{C}_{18} \mathrm{H}_{16} \mathrm{~S}$ C 81.77, H 6.10, S 12.13\%

1,3-Bis[4,8-dimethylazulen-6-yl]-2-(thien-2-yl)propane (20). Violet oil; ${ }^{1} \mathrm{H}-\mathrm{NMR}\left(\mathrm{CDCl}_{3}, \delta\right.$, ppm): 2.89 (s, $\left.12 \mathrm{H}, \mathrm{Me}_{4}, 8^{\prime}\right), 3.19$ (dd, ${ }^{2} J=13.0 \mathrm{~Hz},{ }^{3} J=8.1 \mathrm{~Hz}, \mathrm{H}, 1(3)-\mathrm{H}_{\mathrm{a}}$ ), 3.26 (dd, ${ }^{2} J=13.0$ $\mathrm{Hz},{ }^{3} J=7.7 \mathrm{~Hz}, 2 \mathrm{H}, 3(1)-\mathrm{H}_{\mathrm{b}}$ ), 3.76 (quintet, $\left.{ }^{3} J=7.9 \mathrm{~Hz}, 1 \mathrm{H}, 2-\mathrm{H}\right), 6.54$ (d, ${ }^{3} J=3.5 \mathrm{~Hz}, 1 \mathrm{H}, 3$ "H), $6.82\left(\mathrm{dd},{ }^{3} J=5.0 \mathrm{~Hz},{ }^{3} J=3.5 \mathrm{~Hz}, 1 \mathrm{H}, 4^{\prime}\right.$ '-H), 6.95 (s, $\left.4 \mathrm{H}, 5^{\prime}-\mathrm{H}, 7^{\prime}-\mathrm{H}\right), 7.17$ (d, ${ }^{3} J=5.0 \mathrm{~Hz}$, $\left.1 \mathrm{H}, 5^{\prime}-\mathrm{H}\right), 7.41$ (d, $\left.{ }^{3} J=3.9 \mathrm{~Hz}, 4 \mathrm{H}, 1^{\prime}-\mathrm{H}, 3^{\prime}-\mathrm{H}\right), 7.74$ (t, $\left.{ }^{3} J=3.9 \mathrm{~Hz}, 2 \mathrm{H}, 2^{\prime}-\mathrm{H}\right){ }^{12}{ }^{12}$ MS (ESI): 435 [M+1]. Found C 85.59, H 6.99, S 7.42\% Calcd. for $\mathrm{C}_{31} \mathrm{H}_{30} \mathrm{~S} \mathrm{C} 85.67, \mathrm{H} 6.96, \mathrm{~S} 7.38 \%$

1-(4,8-Dimethylazulen-6-yl)-2-(thien-2-yl)-3-(6,8-dimethylazulen-4-yl)propane (21). In mixture with a small amount of isomer 20 as green oil; ${ }^{13}{ }^{1} \mathrm{H}-\mathrm{NMR}\left(\mathrm{CDCl}_{3}, \delta, \mathrm{ppm}\right): 2.54(\mathrm{~s}, 3 \mathrm{H}$, $\mathrm{Me}_{6}$ ), 2.87 (s, $6 \mathrm{H}, \mathrm{Me}_{4}{ }^{\prime}, 8^{\prime}$ ), 2.92 (s. $3 \mathrm{H}, \mathrm{Me}_{8^{\prime}}$ ), 3.19 (dd, ${ }^{2} J=13.0 \mathrm{~Hz},{ }^{3} J=8.1 \mathrm{~Hz}, 1 \mathrm{H}, 3-\mathrm{H}_{\mathrm{a}}$ ), $3.26\left(\mathrm{dd},{ }^{2} J=13.0 \mathrm{~Hz},{ }^{3} J=7.7 \mathrm{~Hz}, 1 \mathrm{H}, 3-\mathrm{H}_{\mathrm{b}}\right), 3.47\left(\mathrm{dd},{ }^{2} J=12.9 \mathrm{~Hz},{ }^{3} J=8.0 \mathrm{~Hz}, 1 \mathrm{H}, 1-\mathrm{H}_{\mathrm{a}}\right)$, $3.76\left(\mathrm{dd},{ }^{2} J=12.9 \mathrm{~Hz},{ }^{3} J=7.6 \mathrm{~Hz}, 1 \mathrm{H}, 1-\mathrm{H}_{\mathrm{b}}\right), 4.00$ (quintet, $\left.{ }^{3} J=7,3 \mathrm{~Hz}, 1 \mathrm{H}, 2-\mathrm{H}\right), 6.56\left(\mathrm{~d},{ }^{3} J=\right.$ $4.1 \mathrm{~Hz}, 1 \mathrm{H}, 3$ '”-H), 6.82 (dd, $\left.{ }^{3} J=5.0 \mathrm{~Hz},{ }^{3} J=3.5 \mathrm{~Hz}, 1 \mathrm{H}, 4^{\prime \prime}{ }^{-H}\right), 6.87$ (s, $\left.1 \mathrm{H}, 7^{\prime}-\mathrm{H}\right), 6.95$ (s, 2 H, (5'-H, 7'-H), 7.05 (s, $\left.1 \mathrm{H}, 5^{\prime}-\mathrm{H}\right), 7.16\left(\mathrm{~d},{ }^{3} \mathrm{~J}=5.0 \mathrm{~Hz}, 1 \mathrm{H}, 5^{\prime}\right.$ ''-H), $7.26\left(\mathrm{~d},{ }^{3} J=4.0 \mathrm{~Hz}, 1 \mathrm{H}\right.$, 3'-H), 7.38-7.42 (m, $3 \mathrm{H}, 1^{\prime}-\mathrm{H}, 1$ '- $-\mathrm{H}, 3^{\prime}$ '-H), 7.67 (t, $\left.{ }^{3} J=4.0 \mathrm{~Hz}, 1 \mathrm{H}, 2^{\prime}-\mathrm{H}\right), 7.73$ (t, ${ }^{3} J=3.9 \mathrm{~Hz}$, $1 \mathrm{H}, 2$ "'-H); MS (ESI): 435 [M+1].

2-[(E)-2-(6,8-Dimethylazulen-4-yl)vinyl]thiophene (22). In mixture with a small amount of isomer 19 as green oil; ${ }^{4}{ }^{1} \mathrm{H}-\mathrm{NMR}\left(\mathrm{CDCl}_{3}, \delta\right.$, ppm): $2.71\left(\mathrm{~s}, 3 \mathrm{H}, \mathrm{Me}_{6}\right), 2.91\left(\mathrm{~s}, 3 \mathrm{H}, \mathrm{Me}_{8}\right), 7.09$ $\left(\mathrm{dd},{ }^{3} J=5.0 \mathrm{~Hz},{ }^{4} J=3.6 \mathrm{~Hz}, 1 \mathrm{H}, 4^{\prime}-\mathrm{H}\right), 7.10$ (s, $\left.1 \mathrm{H}, 7-\mathrm{H}\right), 7.23$ (d, $\left.{ }^{3} J=3.1 \mathrm{~Hz}, 1 \mathrm{H}, 3^{\prime}-\mathrm{H}\right), 7.32$ $\left(\mathrm{d},{ }^{3} J=5.0 \mathrm{~Hz}, 1 \mathrm{H}, 5^{\prime}-\mathrm{H}\right), 7.43\left(\mathrm{~d},{ }^{3} J=4.0 \mathrm{~Hz}, 1 \mathrm{H}, 1-\mathrm{H}\right), 7.45(\mathrm{~s}, 1 \mathrm{H}, 5-\mathrm{H}), 7.51\left(\mathrm{~d},{ }^{3} J=15.7\right.$ $\left.\mathrm{Hz}, 1 \mathrm{H},=\mathrm{CH}_{\mathrm{tf}}\right), 7.60\left(\mathrm{~d},{ }^{3} J=4.0 \mathrm{~Hz}, 1 \mathrm{H}, 3-\mathrm{H}\right), 7.73\left(\mathrm{t},{ }^{3} J=4.0 \mathrm{~Hz}, 1 \mathrm{H}, 2-\mathrm{H}\right), 7.91\left(\mathrm{~d},{ }^{3} J=15.8\right.$ $\left.\mathrm{Hz}, 1 \mathrm{H},=\mathrm{CH}_{\mathrm{Az}}\right)$; MS (ESI): $265[\mathrm{M}+1]$.

Bis 4,6-\{2-[(E)-thien-2-yl]vinyl\}-8-methylazulene (23). Green crystals, m.p. $133{ }^{\circ} \mathrm{C}$; ${ }^{1} \mathrm{H}-\mathrm{NMR}$ $\left(\mathrm{CDCl}_{3}, \delta, \mathrm{ppm}\right): 2.95$ (s, $\left.3 \mathrm{H}, \mathrm{Me}_{8}\right), 6.98\left(\mathrm{dd},{ }^{3} J=5.0 \mathrm{~Hz},{ }^{3} J=3.9 \mathrm{~Hz}, 1 \mathrm{H}, 4^{\prime}-\mathrm{H}\right), 7.01\left(\mathrm{dd},{ }^{3} J=\right.$ $5.0 \mathrm{~Hz},{ }^{3} J=3.8 \mathrm{~Hz}, 1 \mathrm{H}, 4$ "'-H), $7.08\left(\mathrm{~d},{ }^{3} J=15.8 \mathrm{~Hz}, 1 \mathrm{H},\left(=\mathrm{CH}_{\mathrm{tf}}\right) 4\right), 7.13\left(\mathrm{~d},{ }^{3} J=4.3 \mathrm{~Hz}, 1 \mathrm{H}\right.$, $\left.3^{\prime}-\mathrm{H}\right), 7.17\left(\mathrm{~d},{ }^{3} J=3.0 \mathrm{~Hz}, 1 \mathrm{H}, 3^{3}-\mathrm{H}\right), 7.21\left(\mathrm{~d},{ }^{3} J=5.0 \mathrm{~Hz}, 1 \mathrm{H}, 5^{\prime}-\mathrm{H}\right), 7.24\left(\mathrm{~d},{ }^{3} J=5.6 \mathrm{~Hz}, 1 \mathrm{H}\right.$, 5“-H), $7.27(\mathrm{~s}, 1 \mathrm{H}, 7-\mathrm{H}), 7.39\left(\mathrm{~d},{ }^{3} J=16.0 \mathrm{~Hz}, 1 \mathrm{H},\left(=\mathrm{CH}_{\mathrm{Az}}\right)_{4}\right), 7.45\left(\mathrm{~d},{ }^{3} J=3.6 \mathrm{~Hz}, 1 \mathrm{H}, 1-\right.$ H), $7.46\left(\mathrm{~d},{ }^{3} J=15.5 \mathrm{~Hz}, 1 \mathrm{H},\left(=\mathrm{CH}_{\mathrm{Az}}\right)_{6}\right), 7.48\left(\mathrm{~d},{ }^{3} J=3,6 \mathrm{~Hz}, 1 \mathrm{H}, 3-\mathrm{H}\right), 7.56(\mathrm{~s}, 1 \mathrm{H}, 5-\mathrm{H}), 7.63$ $\left(\mathrm{t},{ }^{3} J=3.8 \mathrm{~Hz}, 1 \mathrm{H}, 2-\mathrm{H}\right), 7.82\left(\mathrm{~d},{ }^{3} J=15.5 \mathrm{~Hz}, 1 \mathrm{H},\left(=\mathrm{CH}_{\mathrm{tf}}\right)_{6}\right) ;{ }^{13} \mathrm{C}-\mathrm{NMR}\left(\mathrm{CDCl}_{3}, \delta, \mathrm{ppm}\right): 25.8$ $\left(\mathrm{Me}_{8}\right), 116.3(\mathrm{CH}), 117.8(\mathrm{CH}), 119.2(\mathrm{CH}), 120.2(\mathrm{CH}), 124.1(\mathrm{CH}), 125.5(\mathrm{CH}), 125.9(\mathrm{CH})$, $126.0(\mathrm{CH}), 127.7(\mathrm{CH}), 127.8(\mathrm{CH}), 128.2(\mathrm{CH}), 130.2(\mathrm{Cq}), 133.9(\mathrm{CH}), 134.2(\mathrm{CH}), 142.4$ (Cq); MS (ESI): 359 [M+1]. Found C 77.00, H 5.15, S 17.85\% Calcd. for $\mathrm{C}_{23} \mathrm{H}_{18} \mathrm{~S}_{2} \mathrm{C} 77.05, \mathrm{H}$ $5.06, \mathrm{~S} 17.89 \%$

2-(4,8-Dimethylazulen-6-yl)-1-(thien-2-yl)ethanone (24). Violet crystals, m.p. $121{ }^{\circ} \mathrm{C}$; UV (hexane, $\lambda(\mathrm{nm}) / \log (\varepsilon)): 247$ (4.21), 287 (4.52), 314 (4.39), 566 (2.68); ${ }^{1} \mathrm{H}-\mathrm{NMR}\left(\mathrm{CDCl}_{3}, \delta\right.$, 
ppm): 2.93 (s, $\left.6 \mathrm{H}, \mathrm{Me}_{4,8}\right), 4.36\left(\mathrm{~s}, 2 \mathrm{H}, \mathrm{CH}_{2}\right), 7.13$ (dd, ${ }^{3} J=5.0 \mathrm{~Hz},{ }^{3} J=3.9 \mathrm{~Hz}, 1 \mathrm{H}, 4$ '-H), 7.15 $(\mathrm{s}, 2 \mathrm{H}, 5-\mathrm{H}, 7-\mathrm{H}), 7.43\left(\mathrm{~d},{ }^{3} J=4.0 \mathrm{~Hz}, 2 \mathrm{H}, 1-\mathrm{H}, 3-\mathrm{H}\right), 7.65\left(\mathrm{dd},{ }^{3} J=4.9 \mathrm{~Hz},{ }^{4} J=1.1 \mathrm{~Hz}, 1 \mathrm{H}\right.$, 5'-H), $7.76\left(\mathrm{t},{ }^{3} \mathrm{~J}=3.9 \mathrm{~Hz}, 1 \mathrm{H}, 2-\mathrm{H}\right), 7.81\left(\mathrm{dd},{ }^{3} \mathrm{~J}=3.8 \mathrm{~Hz}, 1 \mathrm{H}, 3^{\prime}-\mathrm{H}\right) ;{ }^{13} \mathrm{C}-\mathrm{NMR}\left(\mathrm{CDCl}_{3}, \delta\right.$, ppm): $25.3\left(\mathrm{Me}_{4,8}\right), 52.6\left(\mathrm{CH}_{2}\right), 116.8(\mathrm{CH}), 127.5(\mathrm{CH}), 128.4(\mathrm{CH}), 133.0(\mathrm{CH}), 133.9(\mathrm{CH})$, $134.4(\mathrm{CH}), 136.9(\mathrm{Cq}), 141.6(\mathrm{CH}), 145.9(\mathrm{CH}), 146.5(\mathrm{Cq}), 190.3(\mathrm{CO}) ; \mathrm{MS}(\mathrm{ESI}): 281$ [M+1]. Found C 77.06, H 5.84, S 11.41\% Calcd. for $\mathrm{C}_{18} \mathrm{H}_{16} \mathrm{SO}$ C 77.11, H 5.75, S 11.44\%

2-(6,8-Dimethylazulen-4-yl)-1-(thien-2-yl)ethanone (25). In mixture with the compound 24 as violet oil; ${ }^{4}{ }^{1} \mathrm{H}-\mathrm{NMR}\left(\mathrm{CDCl}_{3}, \delta\right.$, ppm): 2.65 (s, $\left.3 \mathrm{H}, 8-\mathrm{H}\right), 2.91(\mathrm{~s}, 3 \mathrm{H}, 6-\mathrm{H}), 4.76\left(\mathrm{~s}, 1 \mathrm{H}, \mathrm{CH}_{2}\right)$, $7.10\left(\mathrm{dd},{ }^{3} J=5.0 \mathrm{~Hz},{ }^{3} J=3.9 \mathrm{~Hz}, 1 \mathrm{H}, 4^{\prime}-\mathrm{H}\right), 7.14$ (s, $\left.1 \mathrm{H}, 7-\mathrm{H}\right), 7.15$ (s, $\left.1 \mathrm{H}, 5-\mathrm{H}\right), 7.39-7.43$ (m, $2 \mathrm{H}, 1-\mathrm{H}, 3-\mathrm{H}) 7.65\left(\mathrm{dd},{ }^{3} J=4.9 \mathrm{~Hz},{ }^{4} J=1.1 \mathrm{~Hz}, 1 \mathrm{H}, 5^{\prime}-\mathrm{H}\right), 7.72\left(\mathrm{t},{ }^{3} J=3.9 \mathrm{~Hz}, 1 \mathrm{H}, 2-\mathrm{H}\right)$, $7.85\left(\mathrm{dd},{ }^{3} \mathrm{~J}=3.8 \mathrm{~Hz}, 1 \mathrm{H}, 3^{\prime}-\mathrm{H}\right)$; MS (ESI): 281 [M+1].

\section{Acknowledgements}

The financial support of this research, received from the Ministry of Education and Research, Romania, Excellence Research Programs- Contract No. 2 CEEX 06 - 1143 / 25.07.2006, is gratefully acknowledged.

\section{References and Notes}

1. Razus A. C.; Nitu C.; Tecuceanu V.; Cimpeanu V. Eur. J. Org. Chem. 2003, 4601.

2. Lete C.; Esteban B. M.; Kvarnstromb C.; Razus A. C.; Ivaska A. Electrochimica Acta 2007, $52,6476$.

3. Horino H.; Asao T.; Inoue N. Bull. Chem. Soc. Jpn. 1991, 64, 183, and references therein.

4. The term "anil synthese" was used by Siegrist for the condensation of an aromatic methyl group with Schiff bases obtained from aniline in the presence of fine powered $\mathrm{KOH}$ in dimethylformamide: Siegrist A. E. Helv. Chim. Acta 1967, 50, 906. Siegrist A. E.; Liechti P.; Meyer H. R.; Weber K. Helv. Chim. Acta 1969, 52, 2521.

5. Briquet A. A. S.; Hansen H. J. Helv. Chim. Acta 1994, 77, 1921.

6. As expected, the reactivity of "anils" used was inverted compared with the reactivity of the compounds $4-\mathrm{XC}_{6} \mathrm{H}_{4} \mathrm{CH}=\mathrm{NC}_{6} \mathrm{H}_{5}$ described in ref. 4.

7. The formation in $2 \%$ yield of such a product was reported by Briquet and Hansen in the reaction of guaiazulene only with the anil obtained from 4-chlorobenzaldehyde.

8. Song J.; Hansen H.-J. Helv. Chim. Acta 1999, 82, 309.

9. The MOPAC 7.0 package and AM1 approach were used.

10. Owing to the small amount of diastereoisomers mixture available unambiguous assignment of several proton signals was not possible. Moreover, the overcrowded ${ }^{13} \mathrm{C}-\mathrm{NMR}$ spectra of these compounds are not analyzed. 
11. Mixed with a small amount of $\mathbf{1 7}$ for which only MS was recorded.

12. The ${ }^{13} \mathrm{C}-\mathrm{NMR}$ spectra of compounds $\mathbf{2 0}$ and $\mathbf{2 1}$ are not recorded due to the small amount of the mixture of these two isomers obtained. Only compound $\mathbf{2 0}$ was obtained as a pure product after subsequent separation.

13. The purification of several compounds failed therefore their characterization was made only by ${ }^{1} \mathrm{H}-\mathrm{NMR}$ and mass spectra. 